\title{
Hindrance to Benefit from the Potential Sources of Finance to Enhance the Growth of Small and Medium Size Enterprises in South Africa
}

\author{
Paul Saah* and Wedzerai S. Musvoto
}

\begin{abstract}
School of Management Sciences, Faculty of Economic and Management Sciences, North West University, South Africa
\end{abstract}

\begin{abstract}
Small and Medium Size Enterprises are increasing playing an important role in economic development of most countries all over the world nowadays. For these small businesses to grow and be sustainable, they require sufficient capital in the form of financial resources to go operational because the lack of funding or access to finance could hamper their growth. The lack of access to finance has been reported to be one of the major causes of small business failure and discontinuity in South Africa. The purpose of this study is to identify the available sources of financial support for the growth of SMEs in South Africa. The study anticipates to find out why despite government's effort to offer financial support for the growth of the SME sector, the rate of small business failure and discontinuity in South Africa is still one of the highest in the world. A qualitative methodological approach was utilized and interviews were conducted on SME managers on the subject under investigation. It was found that most SME managers in South Africa are ignorant about available sources of finance offered by government to boost the sector. It is imperative for the relevant authorities to revise and improve on the means and mechanisms used to support SMEs such that all small business managers are aware of the availability of this assistance and where and how to access it. In this regard, the government need to set up education and training facilities in different communities where intending and existing small business managers would be educated on the available sources of finance and how to access this funding to start up and grow their businesses.
\end{abstract}

Keywords: Finance, SMEs, failure, success, business, South Africa.

\section{INTRODUCTION}

Recently, there has been a growing awareness of the important role that Small and Medium Size Enterprises (SMEs) play in the economic development of South Africa. This is because SMEs are increasingly becoming more efficient and prolific in job creation and contribution to the GDP than larger enterprises (Mutoko and Kapunda, 2017). Hence, SMEs are said to be the stream that flows into large businesses to keep them moving and fuels the economic engine of South Africa to expand the economy. Given the recognition of the importance of the SME sector to economic development, the South African government has recently started to formulate policies and initiatives such as financial and technical support to promote the growth of the sector through its relevant departments and agencies. Baliyan (2013) argues that inadequate financing is a major hindrance to the growth of SMEs in most countries. Apart from government's initiatives of offering financial and technical support to SMEs, most small businesses rely on commercial banks for their financing. Moore et al. (2010) affirm that even though SMEs are playing an important role in economic development, they are faced with some challenges

*Address correspondence to this author at the School of Management Sciences, Faculty of Economic and Management Sciences, North West University, South Africa; Tel: +27719693489; E-mail: Saahpaul10@gmail.com such as lack of finance that threaten their growth and hinders them from tapping into existing business opportunities.

Due to their highly conservative nature, SMEs are facing limitations of access to finance from South African banks because these institutions are more inclined to lend money only to businesses that are already in their later stages of development. This means that commercial banks are not willing to lend money to start-up SMEs especially because most of them do not meet the basic requirements for obtaining loans such as lack of credit history, inadequate collateral security and inability to produce a satisfactory business plan (BER, 2016). Rungani and Potgieter (2018) note that South Africa has a range of funding schemes for SMES provided by both private and the public sector funding departments and agencies. Micro finance institutions also have structures for small loans, but there are of very high interest rates that the start-up small businesses cannot afford. However, there is a low level if not the lack of awareness on the part of the beneficiaries for these programmes about these exiting funding scheme especially for government sponsored schemes and even the funding provided by private agencies and financial institutions. Chimucheka (2016) asserts that it is difficult to determine with certainty if the financial and technical assistance provided by the South African government, other private agencies and 
financial institutions are sufficient to meet the needs of SMEs to trigger their growth and ensure their sustainability especially with regard to the specific causes for the lack of access to these schemes.

SMEs actually need sources of funding for their expansion and growth. In this regards, a number of suitable legislations have been introduced in South Africa to support the growth of small businesses as an attempt to resolve some of the problems plaguing the sector (BER, 2016). Despite government effort to provide financial and even technical support to SMEs through relevant department and agencies in order to enhance the growth of the sector, unfortunately business reports and authors such as Rungani and Potgieter (2018) stipulate that the small business failure in South Africa is still one of the highest in world. Only 27 percent of start-up small businesses expect to obtain loans from commercial banks and/or gain access to formal financial support offered through the relevant government departments and agencies in South Africa (Mqaba 2015). Hence, the lack of external source of capital (venture equity), makes many SMEs to dependent on supplier credit, overdrafts, friends' support and family support for early stage financing which is hardly enough to grow their businesses.

The identification of the major issue associated with the failure and discontinuity of SMEs in South Africa, which is inadequate financing, is a call for the need to reveal the sources of finances for small businesses in order to curb this problem upsetting the sector. This will assist in creating awareness for the small business managers about the availability of financial and even technical support for their businesses. What then are the sources of finance for the growth of SMEs in South Africa? This study focuses on identifying the available sources of financial support for the growth of SMEs in order to reduce their failure rate in South Africa. Against this background, the objective of this study was to determine and test the challenges that are hindering SME managers to benefit from this financial support to grow their businesses.

\section{GROWTH TREND OF SMES IN SOUTH AFRICA}

Despite a number of suitable legislations introduced in South Africa to support the growth of SMEs, GEM (2014) reports that the growth of newly established small businesses keeps declining over the years. The decline of SME growth in South Africa indicates a negative expansion of these businesses over the years. This implies that instead of the growth of the sector, SMEs in South Africa are still experiencing a high rate of failure and discontinuity, which is even one of the highest in the world. Bruwer and Watkins (2010) note that SMEs in South Africa have a general yearly failure rate in the range of 70 and 80 percent. Rungani and Potgieter (2018) affirms that one of the reasons for the high rate of SMEs failure in South Africa is the lack of access to finance. The negative growth trend (failure rate) of SMEs in South Africa is illustrated in Figure 1.

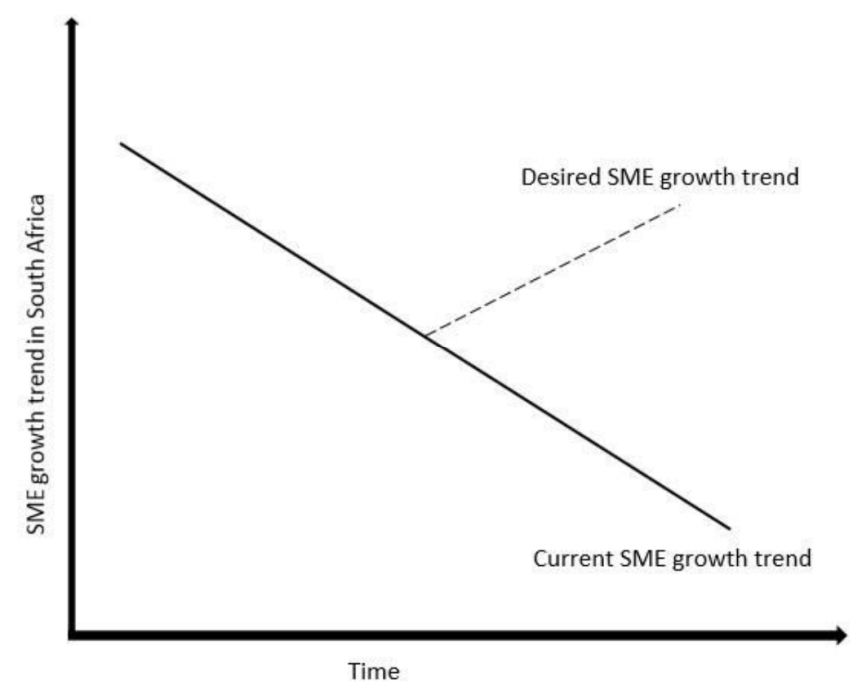

Figure 1: The downward trend of SME growth rate in South Africa.

Source: Adapted from Leboea (2017).

Figure 1 above depict the downward trend of SME growth in South Africa over time. The continuous line that slops downwards from left to right show the current trend of SME growth in South Africa. The discontinued line that runs upward from left to right depicts the desired SME growth trend if small business managers can be able to access the available sources of finance to grow their businesses. If the current SME growth trend (failure rate) is left unchecked, and no interventions such as enforcing financial and technical support to this sector through relevant government departments and agencies, this current failure rate might continue until very few SMEs will be operational in South Africa in the nearest future. The growth trend of SMEs in South Africa indicates that their failure and discontinuity rate is very high and must be address.

\section{SOURCES OF FINANCE FOR SMES' GROWTH IN SOUTH AFRICA}

All small businesses require sufficient capital in the form of financial resources for them to go operational in trading to grow. Bell (2015) argues that improving SMEs' access to finance and finding solutions to unlock 
sources of capital is crucial in enabling this potentially dynamic sector to grow. Labuschagne (2015) affirms that the South African governments seeks to provide a supportive environment for growing SMEs because the challenges faced by this sector require that the government implore new strategies and tools to help promote the growth of these businesses. As far back as 1996 the Small Business Act number 102 of 1996 (SA, 1996) was applied, followed by the Small Business Amendment Act in 2003 which gave guiding principles to the South African government to support the development the SME sector (OECD, 2010). BER (2016) contend that to develop the SME sector in South Africa, the government ensures that funds are distributed to small businesses through various departments and agencies but disappointingly, most SME managers do not have the necessary information on how to access this funding. The departments and agencies that offer support to SMEs are: the Department of Trade and Industry (DTI), Department of Small Business Development (DSBD), the Presidency, Small Enterprise Development Agency (SEDA), National Empowerment Fund (NEF), Small Enterprise Finance Agency (SEFA), Commercial Banks and South African Micro Finance Apex Fund (SAMAF).

The DTI is responsible for the development and review of policies related to SMEs in order to create a conducive environment for the formation and growth of small business enterprises to accelerate the expansion of the sector. The DTI most urgent tasks in terms of SME development include reviewing of the Hire Purchase Act, the Credit Agreements Act and the Usury Act, and replacing them with predominant credit legislation (DTI 2008). Therefore, this department assist to foster the development of the SME sector by improving credit exposure and status of pledges for SMEs, creating a simple uniform system for the registration and enforcement of commercially secured loans on SME repayment profiles. Dhanah (2017) stipulates that in order to promote the growth of the SME sector in South Africa, the DTI has created quite a number of programmes to encouragement the growth of small businesses. These schemes include the following: Small and Medium Manufacturing Development Programme (SMMDP), Small Medium Enterprise Development Programme (SMEDP), Economic Empowerment Schemes (EES), Venture Capital Scheme, Import Finance Scheme, Normal Finance Scheme

Short-term export finance guarantee facility and Export Marketing and Investment Assistance (EMIA) scheme. There are also publications on the government funding schemes, which are useful for SME managers to guide them on how and where to obtain financial support for their businesses. According to NCR (2011), information concerning the support programmes for SMEs can be access from various sources, the most comprehensive of which is perhaps the DTI website and compiled in the DTI's national directory of small business support programmes.

The Department of Small Business Development focuses on growing the number of small enterprises that it supports by reviewing the strategy for SME development, developing the markets for small enterprises, developing and supporting cooperatives, supporting incubators for small enterprises, and strengthening departmental operational capacity (DSBD, 2016). Fuzile (2016) maintains that the DSBD imposes appropriate sanctions on municipalities that do not comply with paying small enterprises within the stipulated period of 30 days. DSBD (2016) affirms that the Department of Small Business Development has a mandate, a vision and a mission that are aimed to support the development of SME sector to ensure the growth of small business enterprises in the South African. The department makes the business environment conducive for the development and growth of small business enterprises and cooperatives by providing improved monetary and non-monetary support services and leveraging on community and private enterprises (DSBD, 2016). Fuzile (2016) asserts that increasing the number of SMEs that the DSBD assists to grow and survive by providing financial support and non-financial interventions will be the department's biggest spending focus in the medium term, reflected in subsidies of R3.7 billion and comprising 84.7 percent of its total budget. Therefore, SMEs can take advantage of the administrative, technical, and financial assistance offered by the DSBD to grow their business and be sustainable.

Since 1994, the presidency of South Africa has prioritised the development of SMEs in its policy agenda. The initial step taken by the South African presidency to foster the development small business enterprises in the country was the implementation of the White Paper on a nationwide strategy for the encouragement and development of SME sector in March 1995 (Hadebe, 2010). This initial attempt to establish an effective guiding framework for small business enterprises was the endorsement of the National Small Business Act 102 of 1996 by the government. Dhanah (2017) asserts that the National 
Small Business Act 102 of 1996 resulted in the establishment of many development finance institutions that uninterruptedly adjust their product offerings to suit the dynamism of the country's economy. These development finance institutions include National Empowerment Fund (NEF), the Khula Enterprise Finance Ltd (KHULA), the Umsobomvu Youth Fund (UYF) and Ntsika Enterprise Promotion Agency (NEPA). Hadebe (2010) affirms that the Department of Finance, with the support of the South African presidency, continues to decrease the corporate tax rate on SMEs, for instance $1 \%$ reduction from 29 percent to 28 percent in 2009 , to encourage the development of small business sector. More so, the South African Revenue Services (SARS) with the authorisation of the presidency is unceasingly granting tax breaks to SMEs to accomplish a similar objective as the Department of Finance. Therefore, SME managers need to take advantage of these initiatives by the South African presidency to support the growth of the sector to ensure the survival of their small business enterprises.

Labuschagne (2015) avers that SEDA was formed in December 2004 through the National Small Business Amendment Act 29 of 2004 with the mandate to integrate government-funded SMEs and design a standard distribution network for SME expansion. Wiese (2014) affirms that SEDA is responsible for initiating a national entrepreneurship drive, strengthening assistance for SMEs' access to finance, increasing education and training for small businesses as well as funding small business infrastructure amenities in indigenous communities across the country. This explains why SEDA is creating partnerships with other agencies so that together, they can contribute to develop the SME sector. Hadebe (2010) affirms that SEDA has created solid partnerships with other agencies and financial institutions such as the National Empowerment Fund (NEF), Development Finance Institutions (DFI), South African Micro Finance Apex Fund (SAMAF), Sector Education and Training Authorities (SETAs) in order to foster the development of the SME sector. SEDA offers business assistance to SMEs through developing of marketing material, developing of small business plans and through training, mentoring and coaching these businesses to ensure their growth (Motsetse, 2015). This initiative of SEDA to support and promote the development of the SME sector is an opportunity for SME managers to benefit from and take advantage of the largess of the agency to grow their businesses.
The National Empowerment Fund (NEF) was created by the National Empowerment Fund Act, 1998 (Act No. 105 of 1998) mandated to promote and facilitate black economic participation by giving nonfinancial and financial assistance to black business enterprises and promote a culture of savings and investment among black people. This agency offers business loans from R250 000 to R75 million for setting up of new businesses (start-ups), the growth of the existing ones and equity acquisition across all the sectors of the South African economy (Garach, 2017). Motsetse (2015) states that the agency helps with the procurement of stocks in private and public companies and gives financial support of not less than R250 000 to most enterprises owned and managed by historically disadvantaged individuals. According to NEF (2015), there are different forms of financial support offered by National Empowerment Fund, which are entrepreneurship finance, procurement finance, new venture finance and strategic projects fund. This is proof that empowering and assisting the development of small businesses owned by historically underprivileged individuals is a priority of the National Empowerment Fund.

Municipal Focus (2012) notes that SEFA services small business concerns that need funding up to R3 million, with its lending instruments which include credit guarantees for businesses requiring bank finance, wholesale loans to financial intermediaries and direct lending to small business enterprises. Motsetse (2015) states that SEFA provides services to small businesses such as the provision of equity or capital and gearing for start-up businesses, offering credit guarantee scheme, and private sector funding for small business concerns in certain sectors. More so, the agency assists in financing SMEs through collaborating with financial intermediaries, granting loans ranging from R50 000 to R5 million. Hussain (2006) asserts that SEFA has the tasks to instigate and encourage commercial banks to implement best practices to foster the growth of SMEs, to create a conducive environment for banks to increase credit flow to small businesses. SEFA chief executive - Thakhani Makhuvha, speaking to Small Business Connect indicated that the agency intends to disburse at least R200 million in funding annually for the development of small business sector in South Africa and that the agency would like to see and welcome enterprising youths applying for funding to set up new business ventures (Chauke, 2014). With the amount of R200 million a year in funding from SEFA, SME managers, especially youth-owned small 
business enterprises stand a greater chance to benefit from this finance scheme to grow their businesses.

Before, it used to be difficult for SMEs to obtain funding from commercial banks but there is great news now for those small business ventures that are striving because contact for funding and investment are no more an issue (National Credit Regulator, 2011). With the intervention of some agencies such as SEDA, NEF and SEFA, investment and financial opportunities are accorded to the SMEs in South Africa by commercial banks. For example, according to Kalane (2015), unlike before, in 2014 about two thirds of overdraft and credit applications submitted by SMEs to commercial banks were granted. Hussain (2006) contend that the South African government has mandated some departments such as the Department of Small Business Development and some agencies such as Small Enterprise Development Agency and National Empowerment Fund to support banks to adopt best practices that lead to the growth of SMEs. Government programmes supporting the SME sector include financing programmes using guarantees, some of which are given by Khula. The Khula Credit Indemnity Scheme was created to provide access to funding for individuals who desire to expand or start up SMEs but do not have adequate collateral security required by commercial banks to obtain loan (NCR, 2011). Since South African commercial banks are now according investment and financial opportunities to SMEs unlike before due to the intervention of some agencies such as SEDA, NEF and SEFA, small business managers need to take advantage of this to apply for more bank loans to finance and grow their businesses.

The South African Micro-Finance Apex Fund (SAMAF) was created to give reasonable financial services such as institutional and client capacity building, assist social capital mobilisation through cooperatives most importantly, granting micro-loans to SMEs (SAMAF, 2008). The SAMAF has a mandate to offer accessible and affordable financial services through facilitating training and capacity building for financial intermediaries and micro-entrepreneurs and guaranteeing effective financial intermediation between SME owners and financial institutions (IFC, 2006). The Micro-Finance Apex Fund gives micro finance credit loans to small business enterprises at interest rates of only five to eight percent. In 2007, four micro-finance institutions and thirty-four financial services had either been offered operative backing or approved by the Apex Fund to the total sum of R69.6 million (Sabinet, 2007). (SAMAF, 2017) states that SAMAF offers microfinance to its funded financial intermediaries, such as microfinance institutions (MFIs) and financial services cooperatives (FSCs) who on-lend to their clients and members. More so, it provides capacity building incentives such as working capital and training funds as well as micro-enterprise loans to the financial intermediaries who on-lend to the poor individuals, especially in rural communities to establish and grow their own micro survivalist business ventures. Since SAMAF gives micro finance credit loans to individuals to establish and grow their own small business ventures, small business managers and potential poor entrepreneurs can access these loans to finance and grow their businesses.

\section{RESEARCH METHODS}

Qualitative research approach was used for the collection and analysis of data, which led to the outcome of the findings for this study. The choice of qualitative method employ in this study is because it was most suitable to provide an accurate description of the phenomenon under investigation, which gave a better understanding of the available sources of finance for SMEs and the challenges hindering small businesses managers from accessing this funding to grow their businesses. Johnson and Christensen (2008) avers that qualitative data consists of openended questions that are ask to get information by interviewing participants which allows them to respond in their own words to give a better understand of a complex situation. Zohrabi (2013) assert that the fundamental reason for conducting an interview is to disclose existing knowledge of participants' perceptions in the form of answers that can be made accessible for interpretation in a study. The data for this study was collected by conducting interviews with SME managers around South Africa who constituted the research participants. The sample size for this study was 20 small business managers because the interview got saturated after this number of participants were interviewed since most of them shared the same opinion. A judgmental sample method was use in selecting the 20 participants for the interview.

The qualitative analysis that was perform for this study is thematic analysis with the use of Atlas Ti, free quotations. Johnson and Christensen (2008) stipulate that thematic analysis is a method of analysis in qualitative study that put emphasis on pinpointing, examining, and recording patterns, otherwise known as themes within a data set. Themes are patterns across data sets, which are essential for the description of a 
phenomenon and are connected to a particular research question. Nowell et al. (2017) argue that thematic analysis is carry out in qualitative research study to be able to identify, analyse, organize, describe, and report themes that are within a data set in order to produce trustworthy and insightful findings. Thematic approach was therefore use in order to ensure that meaningful information is drawn from the data collected for the study.

\section{FINDINGS}

In the course of the interviews conducted, 20 small business managers in South Africa were interviewed before attending saturation. The presentation and interpretation of results was done according to themes generated from the data obtained from the interview questions that seek to provide answers to the phenomenon under investigation. The interpretation of the results include analysis that correlate the participants' answers or comments with the relevant literature. When analysing the data obtained from interviewing the participants on Atlas Ti, free quotations to get their views on available sources of finance for SMEs, three themes emerged from the data, which are financial benefits to grow SMEs, reasons for lack of financial benefits, and sources of capital for SMEs.

Concerning the theme: financial benefits to grow SMEs, all twenty participants attest to the fact that they have never benefited from any source of finance for their business. When the participants were asked whether they have ever benefited from any source of finance for their business, all the twenty respondents answered "NO" implying that they have never benefited from any source of finance to grow my business. From the responses of the participants on financial benefits to grow their businesses, it is evident that the financial and technical support meant for SMEs by relevant government departments and agencies do not get to them. This probably explain why most SMEs in South Africa are struggling to survive and some of them are winding up because of lack of finance thereby resulting to a high failure rate of businesses in this sector. Due to the important contribution in job creation and the GDP of the economy, the South African governments is seeking to provide a supportive environment for growing SMEs. This is because the challenges require that new strategies and tools be used to help promote the growth of these businesses in the economy. Kalane (2015) avers that the lack of availability of funding or lack of access to finance an SME could hampered the growth and sustainability of the business. This implies that the absence of access to funding is the principal cause of business failure in South Africa. This is an indication that majority of SMEs depend only on internal support mechanisms to survive, reason why most of them are failing to grow.

With regards to the theme: reasons for not benefiting from financial assistance, sixteen business owners freely express their ignorance of lack of knowledge about any existing sources of finance for SMEs and this accounted to the reason why they had never benefitted from the available sources of finance for SMEs in South Africa. Participants expressed that they are not aware of the available sources of finance more so, they do not even know where to go to get the information. The exact words of participants as generated by Atlas ti free quotations are presented in Figure 2.

Further analysis on Atlas $\mathrm{Ti}$ reveal that access to finance was an issue towards getting funding for SMEs. Three business managers expressed their opinion that their inability of not getting financial assistance is due to lack of access to these available source of finance. Similarly, two small business managers expressed that they do not benefit from the available sources of finance for SME because they do not meet necessary requirements to qualify for most of the schemes to support small businesses financially. Below are some of the responses:

\section{...I have never benefited from these sources of finance because I do not meet the necessary requirement}

\section{... I am not aware of the available sources of finance for SMEs}

\section{... I do not have access to these available sources of finance}

... I do not know where to go to get these finances

The comments of the study participants on the reasons why they do not benefit from financial assistance from relevant government departments and agencies indicates that much still need to be done to reach out to SMEs with financial and even technical support. GEM (2014) reports that most entrepreneurs lack the necessary information and knowledge on how to gain access to finance to fund their businesses before going operational. This is very important for the survival and sustainability of SMEs as BER (2016) 


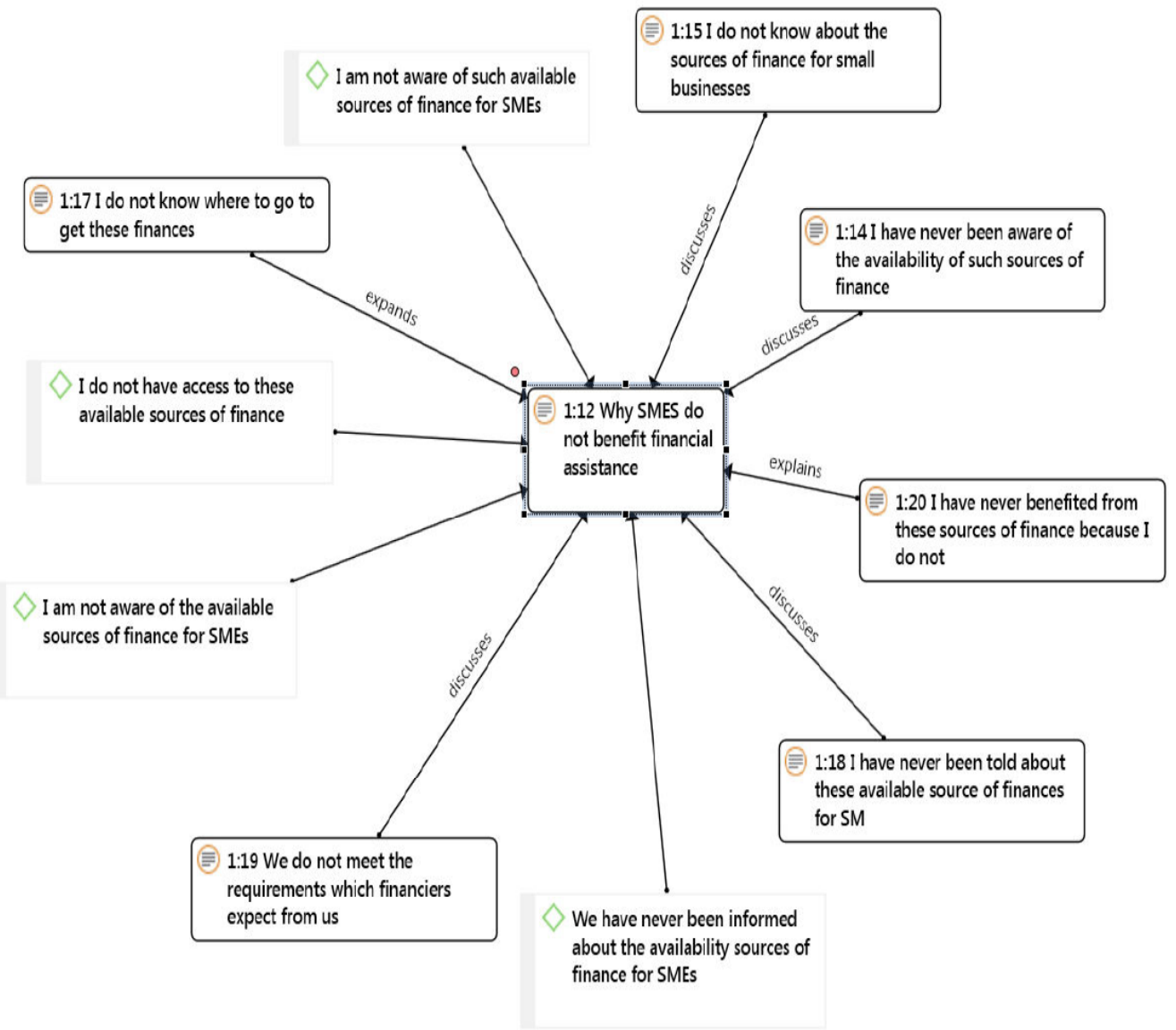

Figure 2: Participants' exact words on why they do not get financial benefits for SMEs.

rightly states that the lack of access to funding causes business failure in South Africa. This implies that majority of SMEs in South Africa depend only on internal support mechanisms to survive, reason why most of them do not grow to become big companies because of ignorance of where and how to get financial support to fund their businesses to survive.

With regards the theme: sources of capital for SMEs, the responses of study participants indicated self-dependence in relation to finance for their businesses. Out of the 20 participants interviewed in this study, ten business owners reported that the source of capital for their businesses is personal savings; five said it was family support, while one depended on friends' support, two depend on personal savings and family support and only two participant reported combining personal savings and friends support. Atlas $\mathrm{Ti}$ assisted to visualize this finding in Figure 3.

From the comments of the study participants regarding the sources of finance for their businesses, all of them depend on internal (self-dependent) means of generating capital for their businesses. This implies that most of them are deprive from external finance and support from relevant government departments and agencies either systematically or out of ignorance. This is very critical because sources of finance are a serious problem for SMEs. According to the responses of the research participants, majority of SME owners got funding for their businesses from private sources such as savings, family support, and friends support, which are often less enough to sustain their businesses.

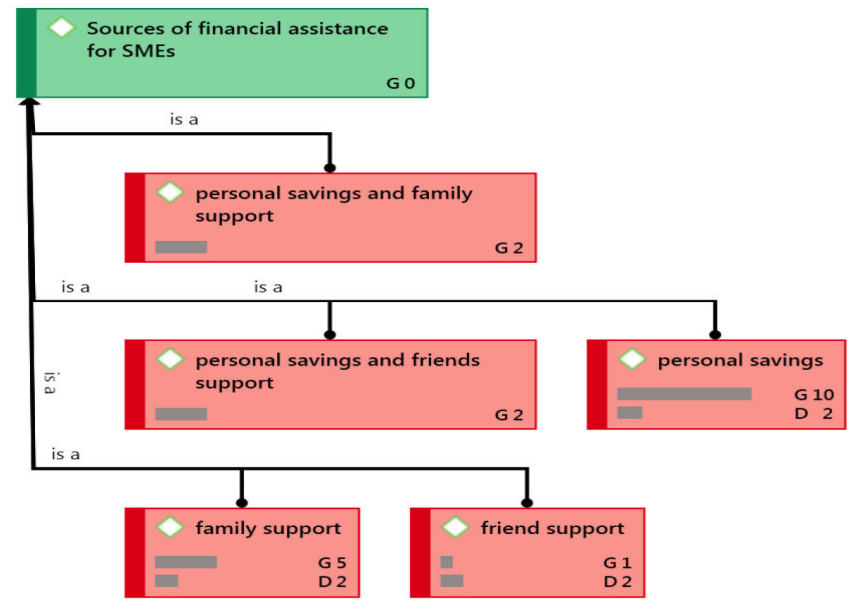

Figure 3: Sources of capital for SMEs. 
Unfortunately, many SMEs cannot acquire financial support from external sources such as relevant government departments and agencies as well as commercial banks because of the lack of basic requirements from the financial system, which include collateral security for loans amongst others (Asplund and Henriksson, 2012).

\section{DISCUSSION}

From the findings of the analysis of this study, there is a need for financial support for SMEs to reach to small business owners. OECD (2006) asserts that many business scholars have hypothesized a financing gap for SMEs, implying that there are considerable number of these businesses that could use funds productively if they were available. Theoretically, this conforms to the financial gap theory, which stipulates that most SMEs require funding from the government and financiers such as the commercial banks which they can make judicious use of the funds to grow their businesses. Unfortunately, many of these SMEs cannot acquire this funding because of the requirements from the financial system (Asplund and Henriksson, 2012). This is because of the inability of SMEs to understand what is required of them to gain access to external sources of finance while the investors find it difficult to mobilise the SMEs because of lack of knowledge about the structure of their business rules and regulations. The financial gap theory advocates for legal funding of SMEs by the government and other financiers such as commercial banks to ensure their growth and survival. This implies that the few SMEs that have benefited and/or are benefiting from some of these external sources of finance are most likely to survive and grow while those that have never benefited and/or are not benefiting from these sources of finance are most likely not to survive. This is because all small businesses require sufficient capital in the form of financial resources for them to go operational in trading to grow (Kalane, 2015). It means that the lack of availability of funding or lack of access to finance for SMEs could hampered the growth of small businesses.

BER (2016) states that the absence of access to funding is one of the major causes of small business failure and discontinuity in South Africa. This is why Bell (2015) thinks that improving SMEs' access to finance and finding solutions to unlock sources of capital is crucial to enable this potentially dynamic sector to grow. A key area of the World Bank Group's work is to improve SMEs' access to finance and find innovative solutions to unlock sources of capital. Credit
Reporting Systems are important as better credit information can lead to increased credit for SMEs. Having acknowledged the contribution of the private sector to the development of the economy by the government, initiatives such as financial assistance must be provided to enhance the growth and sustainability of SMEs. That is why BER (2016) contend that to develop the SME sector in South Africa, the government needs to ensure that funds are distributed to small businesses through various departments and agencies. Disappointingly, according to Bell (2015), most SME managers do not have the necessary information on how to obtain funding from the government to sustain their businesses. Consequently, majority of small business managers do not benefit from the available sources of finance. This implies that disclosing and assisting SMEs with these essential sources of finance available is a means to enable small businesses to gain access to this funding to grow their enterprises to survive and be sustainable. Therefore, it is important for the government to devise measures to foster an improved flow of financing to SMEs to enhance the development of this sector.

External source of finance or capital for small business ventures is an eminent aspect of entrepreneurship that affects the economic life of most individuals and the economy of a country at large. Due to the importance of sources of finance to the growth and survival of SMEs, it is necessary to attend to pertinent issues of funding of small businesses that arose during the course of this study, which can help to resolve the problem plaguing the sector. Since most SMEs managers do not benefit from the financial support for small businesses because of ignorance, the government need to set up education and training facilities where young entrepreneurs can be educated on the available sources of finance and how to access this funding to start up and grow their businesses. The means and mechanisms used by the relevant authorities to support SMEs need to be revisited and improved. To achieve this, the government need to create centres in different communities where intending and existing business managers would not only access sufficient funds for their businesses but also obtain advice from business experts on how to start and run a business successfully. However, SME managers on their part should endeavour to upgrade their level of education to enable them to gain awareness of the external sources of financial and even technical assistance available to support the growth of small business enterprises. This external source of funding is 
meant to augment the internal or self-dependent capital generated by entrepreneurs to fund their businesses so that they can survive, grow and be sustainable.

\section{CONCLUSION}

This study has disclosed the sources of finance that are available to enhance the growth of Small and Medium Size Enterprises in South Africa which could be a solution to unlock bases of capital that is crucial in enabling this potentially dynamic sector to grow. So far, it has been revealed that there are some relevant government departments and agencies as well as commercial banks that offer financial and technical support to SMEs to ensure the growth of the sector. The revelation of these available sources of finance is intended to make SME managers to be aware of this assistance to small enterprises and how they can access this funding to grow their businesses. Nevertheless, this is not a categorical claim that the relevant government departments and agencies as well as commercial banks mentioned in this study are the only sources where SME managers can get external funding to start and grow their businesses. Judging from the findings of this study, it is anticipated that if SME owners can educate their ignorance on the available sources of financial support for small enterprises and how to access it, they will be more likely to benefit from this assistance and experience growth in their businesses.

\section{REFERENCES}

Asplund G, Henriksson J (2012) Reducing the financial gap: How to improve the relationship between entrepreneurs and investors. (Master dissertation, Lund University).

Baliyan SP (2013) Institutions and organisations contributing to entrepreneurship education and skill development in Botswana. Journal of Sustainable Development in Africa 15(5): 1-6.

Bell S (2015) Small and medium enterprises (SMEs) finance. Available at http://www.worldbank.org/en/topic/ financialsector/brief/smes-finance [Date of access: 16/09/2019].

Berry A, Von Blottnitz M, Cassim R, Kesper A, Rajaratnam B, Van Seventer D E (2002) The economics of SMMEs in South Africa, trade and industrial policy strategies. Johannesburg. Government Gazette.

Bruwer J P, Watkins A (2010) Sustainability of fast moving consumer goods retail SMMEs. South African Journal of Business Management 4(16): 3550-3555.

Bureau for Economic Research (2016) The Small, Medium and Micro Enterprise Sector of South Africa. Available at http://www.seda.org.za/Publications/Publications/The\%20Sm all,\%20Medium\%20and\%20Micro\%20Enterprise\%20Sector $\% 20$ of $\% 20$ South $\% 20$ Africa $\% 20$ Commissioned $\% 20$ by $\% 20$ Se da.pdf [Date of access: 20/07/2019].

Chauke A (2014) Fund benefits youth biz. Available at http://www.smallbusinessconnect.co.za/news/fund-benefitsyouth-biz.html\#.WjvTEd-WblU [Date of access: 21/08/2019].
Chimucheka T (2016) The impact of motivational and business orientations of owner-managers on the performance of immigrant-owned SMMEs in South Africa (Doctoral dissertation, University of Fort Hare).

Department of Trade and Industry (DTI) (2008) Annual report 2007 2008, Department of Trade and Industry. Pretoria: Government Gazette.

Dhanah D (2017) Small businesses and job creation in South Africa (Doctoral dissertation, University of Cape Town).

DSBD (2016) South Africa's department of small business development in 2016. Available at https://www.sageone.co. za/2016/12/02/south-africas-department-of-small-businessdevelopment-in-2016/ [Date of access: 22/12/2019].

Fuzile L (2016) Estimates of national expenditure: Small business development. Available at http://www.treasury.gov.za/ documents/national\%20budget/2016/enebooklets/Vote \%203 1\%20Small\%20Business\%20Development.pdf [Date of access: 22/07/2019].

Garach R (2017) The national empowerment fund (NEF). Available at https://www.thedti.gov.za/agencies/nef.jsp [Date of access: 21/07/2019].

GEM (2014) The crossroads a goldmine or a time bomb? Cape Town: Global Entrepreneurship Monitor

Hadebe SP (2010) The impact of wage-setting institutions on the creation and long-term survival of small, medium and microenterprises (SMMES) in South Africa (Doctoral dissertation, University of Johannesburg).

Hussain J (2006) Business start-up and access to finance for SMEs and new technology-based firms. Paper presented at a Conference for the International Network for SME Association, Italy.

International Finance Corporation (IFC) (2006) Access to finance for women entrepreneurs in South Africa, international finance corporation. Johannesburg: Government Gazette.

Johnson B, Christensen L (2008) Educational research: Quantitative, qualitative, and mixed approaches. Sage Publications, Thousand Oaks.

Kalane L (2015) Reasons for failure of SMEs in the Free State (Master's dissertation, University of The Free State).

Labuschagne RC (2015) Assessing selected success factors of SMEs in the North West Province (Master's dissertation, North-West University).

Leboea ST (2017) The factors influencing SME failure in South Africa (Doctoral dissertation, University of Cape Town).

Moore CW, Petty JW, Palich LE, Longenecker JG (2010) Managing small business: An entrepreneurial emphasis, $\left(15^{\text {th }}\right.$ edn). New Delhi: South Western Cengage Learning.

Motsetse MJ (2015) The role of government in developing sustainable SMEs in the construction sector in the Free State province (Doctoral dissertation, University of the Free State).

Mqaba V (2015) The impact of government support on the growth and performance of cooperatives in the Eastern Cape province of South Africa (Master's dissertation, University of Fort Hare).

Municipal F (2012) Leaders in local government business intelligence \& insight. Volume 8, June 2012.

Mutoko WR, Kapunda SM (2017) Factors influencing small, medium and micro-sized enterprises' borrowing from banks: The case of the Botswana manufacturing sector. Acta Commercii, 17(1): $1-9$. https://doi.org/10.4102/ac.v17i1.426

National Credit Regulator (2011) Literature review on small and medium enterprises access to credit and support in South Africa. Available: http://www.ncr.org.za/pdfs [Date of access: 16/06/2019].

Nowell RA, Hollenbeck JR, Gerhart B, Wright PM (2017) Human resource management: Gaining a competitive advantage. McGraw-Hill Education, New York. 
OECD (2006) The SME financing gap: Theory and evidence. https://doi.org/10.1787/fmt-v2006-art11-en

OECD (2010) Social entrepreneurship and social innovation. Available at http://ec.europa.eu/internal_market/social_ business/docs/conference/oecd_en.pdf [Date of access: 22/07/2019].

Rungani EC, Potgieter M (2018) The impact of financial support on the success of small, medium and micro enterprises in the Eastern Cape province. Acta Commercii, 18(1): 1-12. https://doi.org/10.4102/ac.v18i1.591

Sabinet (2007) KHULA, SAMAF \& SEDA brief parliament on SMME funding, June 13. Available at http://www.sabinet.co.za/ sabinetlaw/newspar440.html [Date of access: 10/07/2019].
South African Micro-Finance Apex Fund (SAMAF) (2017) Company overview of South African Micro Finance Apex Fund. Available at https://www.bloomberg.com/research/stocks/ private/snapshot.asp?privcapld=129476559 [Date of access: 10/08/2019].

Wiese JS (2014) Factors determining the sustainability of selected small and medium-sized enterprises (Master's dissertation, North-West University).

Zohrabi M (2013) Mixed method research: Instruments, validity, reliability and reporting findings. Journal of Theory and Practice in Language Studies, 3(2): 254-262. https://doi.org/10.4304/tpls.3.2.254-262

DOI: https://doi.org/10.6000/929-7092.2020.09.39

(C) 2020 Saah and Musvoto; Licensee Lifescience Global.

This is an open access article licensed under the terms of the Creative Commons Attribution Non-Commercial License (http://creativecommons.org/licenses/by-nc/3.0/) which permits unrestricted, non-commercial use, distribution and reproduction in any medium, provided the work is properly cited. 